\title{
Use of the polymerase chain reaction to detect herpes simplex virus DNA in paraffin sections of human brain at necropsy
}

\author{
J A R Nicoll, N J Maitland, S Love
}

\begin{abstract}
The feasibility of detecting herpesvirus DNA in paraffin sections of routinely fixed and processed human necropsy brains by use of the polymerase chain reaction (PCR) was assessed. A 110 bp segment of the thymidine kinase gene of herpes simplex virus type 1 (HSV1) could readily be amplified in sections from the brains of six patients with acute HSV1 encephalitis but not from those of six patients with other neurological diseases, including varicella-zoster encephalitis and herpes simplex virus type 2 encephalitis. Primers suitable for amplifying c-myc were included in the PCRs for assessment of DNA preservation. This was found to be adequate to allow amplification of c-myc DNA in sections from all of the brains studied. The PCR provides a simple and specific means of detecting HSV1 DNA in routinely processed necropsy material.
\end{abstract}

The detection of herpes simplex virus in the central nervous system by conventional histological methods, including immunohistochemistry and electron microscopy, is not usually possible after the first three weeks of the illness, ${ }^{1}$ although data obtained by Southern blot analysis of brains from experimentally infected animals suggests that viral DNA may be detectable for much longer. ${ }^{2}$ Recent demonstration of successful primer-directed amplification of DNA from paraffin sections of biopsy material ${ }^{3}$ prompted us to assess the feasibility of detecting herpes simplex virus
DNA in paraffin sections of human necropsy brains by use of the polymerase chain reaction (PCR).

\section{Methods}

Blocks of formalin-fixed, paraffin-embedded necropsy brain tissue that had been stored for periods ranging from one to 20 years were used. Sections $10 \mu \mathrm{m}$ in thickness were cut from temporal or frontal lobe blocks from six patients with acute herpes simplex virus type 1 (HSV1) encephalitis and six controls (table). The controls included a case of herpes simplex virus type 2 (HSV2) encephalitis and a case of varicella-zoster encephalitis, confirmed serologically. The duration of symptoms in the HSV1 encephalitis patients had ranged from five to 21 days. Two of these patients had had significant rises in the level of serum antibodies to HSV1. The diagnosis of herpes encephalitis had been confirmed in all cases by immunohistochemistry of necropsy brain sections and, in some cases, also by culture and electron microscopy.

The following pairs of oligonucleotide primers, suitable for amplifying a $110 \mathrm{bp}$ fragment of the thymidine kinase gene of HSV1, and a 75 bp fragment of c-myc $c^{5}$ were synthesised in the Department of Biochemistry, University of Bristol: thymidine kinase primers 5'-ATACCGACGATATGCGACCT-3' and 5'-TTATTGCCGTCATAGCGCGG-3', cmyc primers 5'-GGAGGCTATTCTGCCCATTT $-3^{\prime}$ and 5'-TGCAAGGAGAGCCTTTCAGA-3'. The PCR technique was similar to that described by Shibata et al. ${ }^{3}$ The sections were collected in $700 \mu \mathrm{l}$ Eppendorf tubes,

Clinical and laboratory data

\begin{tabular}{|c|c|c|c|c|c|c|c|c|c|}
\hline Case & Age & Sex & Diagnosis & $\begin{array}{l}\text { Duration } \\
\text { of } \\
\text { symptoms }\end{array}$ & Acyclovir & Serology & $\begin{array}{l}\text { Viral } \\
\text { culture }\end{array}$ & $\begin{array}{l}\text { Electron } \\
\text { microscopy }\end{array}$ & $\begin{array}{l}\text { Year of } \\
\text { necropsy }\end{array}$ \\
\hline $\begin{array}{r}1 \\
2 \\
3 \\
4 \\
5 \\
6 \\
7 \\
8 \\
9 \\
10 \\
11 \\
12\end{array}$ & $\begin{array}{l}24 \text { years } \\
15 \text { years } \\
22 \text { years } \\
5 \text { years } \\
70 \text { years } \\
51 \text { years } \\
<1 \text { week } \\
22 \text { years } \\
76 \text { years } \\
81 \text { years } \\
79 \text { years } \\
19 \text { years }\end{array}$ & $\begin{array}{l}\mathbf{F} \\
\mathbf{M} \\
\mathbf{F} \\
\mathbf{M} \\
\mathbf{M} \\
\mathbf{F} \\
? \\
\mathbf{M} \\
\mathbf{F} \\
\mathbf{F} \\
\mathbf{M} \\
\mathbf{F}\end{array}$ & $\begin{array}{l}\text { Acute HSV1 encephalitis } \\
\text { Acute HSV1 encephalitis } \\
\text { Acute HSV1 encephalitis } \\
\text { Acute HSV1 encephalitis } \\
\text { Acute HSV1 encephalitis } \\
\text { Acute HSV1 encephalitis } \\
\text { Perinatal HSV2 encephalitis } \\
\text { Subacute sclerosing panencephalitis } \\
\text { Varicella-zoster encephalitis } \\
\text { Alzheimer's disease } \\
\text { Binswanger's disease } \\
\text { Ruptured berry aneurysm }\end{array}$ & $\begin{array}{l}5 \mathrm{~d} \\
9 \mathrm{~d} \\
12 \mathrm{~d} \\
8 \mathrm{~d} \\
21 \mathrm{~d} \\
15 \mathrm{~d} \\
<1 \mathrm{wk} \\
5 \mathrm{y} \\
21 \mathrm{~d} \\
6 \mathrm{y} \\
6 \mathrm{y} \\
6 \mathrm{~d}\end{array}$ & $\begin{array}{l}\text { yes } \\
\text { no } \\
\text { yes } \\
\text { no } \\
\text { no } \\
\text { no } \\
\text { no } \\
\text { no } \\
\text { no } \\
\text { no } \\
\text { no } \\
\text { no }\end{array}$ & $\begin{array}{l}\overline{+} \\
+ \\
- \\
+ \\
\overline{+} \\
+ \\
\text { nd } \\
+ \\
\text { nd } \\
\text { nd } \\
\text { nd }\end{array}$ & $\begin{array}{l}+ \\
- \\
- \\
+ \\
+ \\
\text { nd } \\
\text { nd } \\
\text { nd } \\
- \\
\text { nd } \\
\text { nd } \\
\text { nd }\end{array}$ & $\begin{array}{l}\text { nd } \\
+^{2} \\
+^{2} \\
+^{2} \\
- \\
+^{2} \\
\text { nd } \\
+^{3} \\
- \\
\text { nd } \\
\text { nd } \\
\text { nd }\end{array}$ & $\begin{array}{l}1980 \\
1986 \\
1986 \\
1984 \\
1984 \\
1970 \\
1983 \\
1985 \\
1980 \\
1989 \\
1989 \\
1989\end{array}$ \\
\hline
\end{tabular}

${ }^{1}$ not done ${ }^{2}$ herpes virus particles ${ }^{3}$ paramyxovirus particles. 


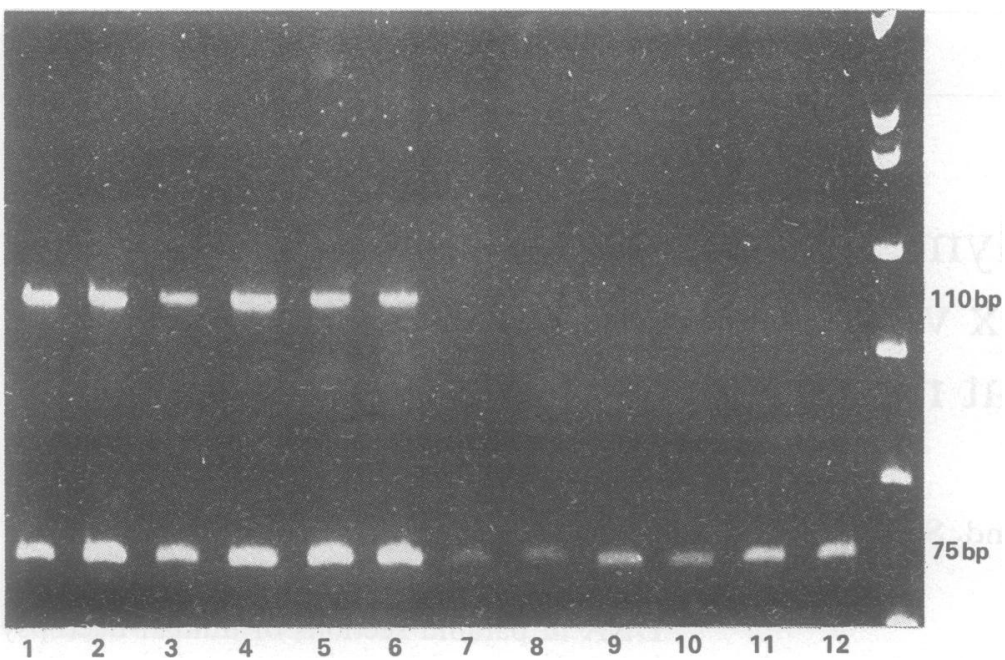

Figure Ethidium bromide staining pattern of the products of HSV1 thymidine kinase and c-myc amplification separated by $10 \%$ polyacrylamide gel electrophoresis. Lanes 1 to 12 correspond to sections from cases 1 to 12 in the table and the lane on the far right contains molecular size markers. The lower bands, present in lanes 1 to 12, are of the $75 \mathrm{bp}$ size predicted for the amplified segment of $c-m y c$. The upper bands, of the $110 \mathrm{bp}$ size predicted for the amplified segment of the HSV1 thymidine kinase gene, are present only in lanes 1 to 6, corresponding to the sections from patients with HSVI encephalitis.

dewaxed by vortexing for one minute in $400 \mu \mathrm{l}$ of xylene and pelleted by centrifugation. The supernatant was discarded and the residual xylene removed by vortexing in two $400 \mu \mathrm{l}$ changes of absolute alcohol. After vacuum desiccation, the samples were resuspended in $50 \mu \mathrm{l}$ of water and heated to $95^{\circ} \mathrm{C}$ for 10 minutes. PCR buffer $(50 \mu \mathrm{l})$ was then added to give final concentrations of $0.02-0.1 \mu \mathrm{M}$ primers, $200 \mu \mathrm{M}$ dNTPs, $50 \mathrm{mM} \mathrm{KCl}$, $1.5 \mathrm{mM} \mathrm{MgCl}_{2}$ and 5 units of Taq polymerase in $10 \mathrm{mM}$ Tris- $\mathrm{HCl}, \mathrm{pH} \mathrm{8.3.} \mathrm{The} \mathrm{mixture} \mathrm{was}$ subjected to 30 thermal cycles, each consisting of denaturation for two minutes at $94^{\circ} \mathrm{C}$, annealing of primers for two minutes at $55^{\circ} \mathrm{C}$, and primer extension for three minutes at $72^{\circ} \mathrm{C}$. Amplified DNA was separated by $10 \%$ polyacrylamide gel electrophoresis, stained with ethidium bromide and visualised by UVinduced fluorescence.

\section{Results}

Detection of viral DNA

In all six cases of acute HSV1 encephalitis examined, including two that had been given acyclovir treatment, DNA fragments of the predicted $110 \mathrm{~kb}$ size were amplified with the thymidine kinase primers (fig). None of the control sections contained detectable HSV1 DNA.

\section{Detection of c-myc}

In all of the sections examined, from both HSV1 encephalitis and control brains, the 75 bp fragment of genomic c-myc DNA was readily amplified (fig). The c-myc amplification seemed to be enhanced in those cases in which there was also amplification of the
$110 \mathrm{bp}$ fragment of the HSV1 thymidine kinase gene (lanes 1-6 in fig). The reason for this is not clear. When the thymidine kinase primers were left out of the reactions the intensity of the c-myc bands was similar in the HSV1 cases and controls.

\section{Discussion}

Present findings show the PCR to be a simple and specific method for the detection of HSV1 DNA in paraffin sections. Rowley et $a l^{6}$ recently reported the use of primer-directed amplification to detect HSV1 DNA in the cerebrospinal fluid of four patients with herpes simplex encephalitis and, as in this study, no false positive or negative results were obtained. The maximum documented duration of illness in their patients was only seven days. Further studies should provide more information as to the duration of detectable infection, the effects of antiviral treatment, and the possible establishment of latent $\mathrm{HSV}$ infection within the central nervous system.

Rogers $e t \mathrm{al}^{7}$ reported that fixation for one week in formalin caused appreciable degradation of the DNA templates with a decline in the efficiency of PCR amplification. However, all the brains examined in this study had been fixed whole for at least three weeks in $10 \%$ unbuffered formalin, processed to paraffin wax over a six day period, and stored for up to twenty years. Blocks of paraffin-embedded tissue are a ready source of a wide range of pathological material suitable for studies of viral and cellular DNA by use of the PCR. Our results indicate that the technique can be applied not only to biopsy material, which is fixed for a relatively short time and then processed to paraffin wax over a period typically less than 24 hours, but also to necropsy specimens fixed for several weeks in formalin and subjected to much longer processing schedules.

We thank Dr Margaret Esiri for providing material from the case of HSV2 encephalitis. This work was supported by the Wellcome Trust.

1 Esiri MM. Herpes simplex encephalitis: an immunohistological study of the distribution of viral antigen within the brain. $J$ Neurol $S c i$ 1982;54:209-26.

2 Efstathiou S, Minson AC, Field HJ, Anderson JR, Wildy P. Detection of herpes simplex virus-specific DNA sequenDetection of herpes simplex virus-specific DNA sequences in latently

3 Shibata DK, Arnheim N, Martin WJ. Detection of human papilloma virus in paraffin-embedded tissue using the polymerase chain reaction. J Exp Med 1988;167:225-30.

4 Lynas C, Cook SD, Laycock KA, Bradfield JWB, Maitland NJ. Detection of latent virus mRNA in tissues using the polymerase chain reaction. $J$ Pathol 1989;157:285-9.

5 Colby WW, Chen EY, Smith DH, Levinson AD. Identification and nucleotide sequence of a human locus homologous to the $v-m y c$ oncogene of avian myelocytomatosis virus MC29. Nature 1983;301:722-5.

6 Rowley AH, Whitley RJ, Lakeman FD, Wolinsky SM. Rapid detection of herpes-simplex-virus DNA in cerebrospinal fluid of patients with herpes simplex encebrospinal fluid of patients with
phalitis. Lancet 1990;335:440-1.

7 Rogers BB, Alpert LC, Hine EAS, Buffone GJ. Analysis of DNA in fresh and fixed tissue by the polymerase chain reaction. Am J Pathol 1990;136:541-8. 